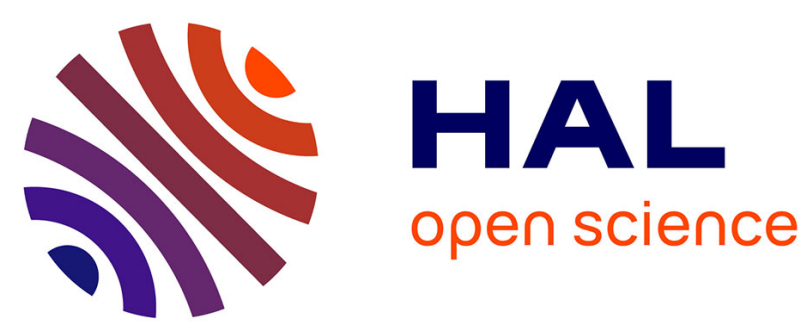

\title{
Design of tailored oxide-carbide coating on carbon fibers for a robust copper/carbon interphase
}

Loic Constantin, Lisha Fan, Qiming Zou, Benjamin Thomas, Jérôme Roger, Jean-Marc Heintz, Catherine Debiemme-Chouvy, Bruno Mortainge, Yong

Feng Lu, Jean-François Silvain

\section{To cite this version:}

Loic Constantin, Lisha Fan, Qiming Zou, Benjamin Thomas, Jérôme Roger, et al.. Design of tailored oxide-carbide coating on carbon fibers for a robust copper/carbon interphase. Carbon, 2020, 158, pp.607-614. 10.1016/j.carbon.2019.11.032 . hal-02361314

\section{HAL Id: hal-02361314 https://hal.science/hal-02361314}

Submitted on 14 Nov 2019

HAL is a multi-disciplinary open access archive for the deposit and dissemination of scientific research documents, whether they are published or not. The documents may come from teaching and research institutions in France or abroad, or from public or private research centers.
L'archive ouverte pluridisciplinaire HAL, est destinée au dépôt et à la diffusion de documents scientifiques de niveau recherche, publiés ou non, émanant des établissements d'enseignement et de recherche français ou étrangers, des laboratoires publics ou privés. 


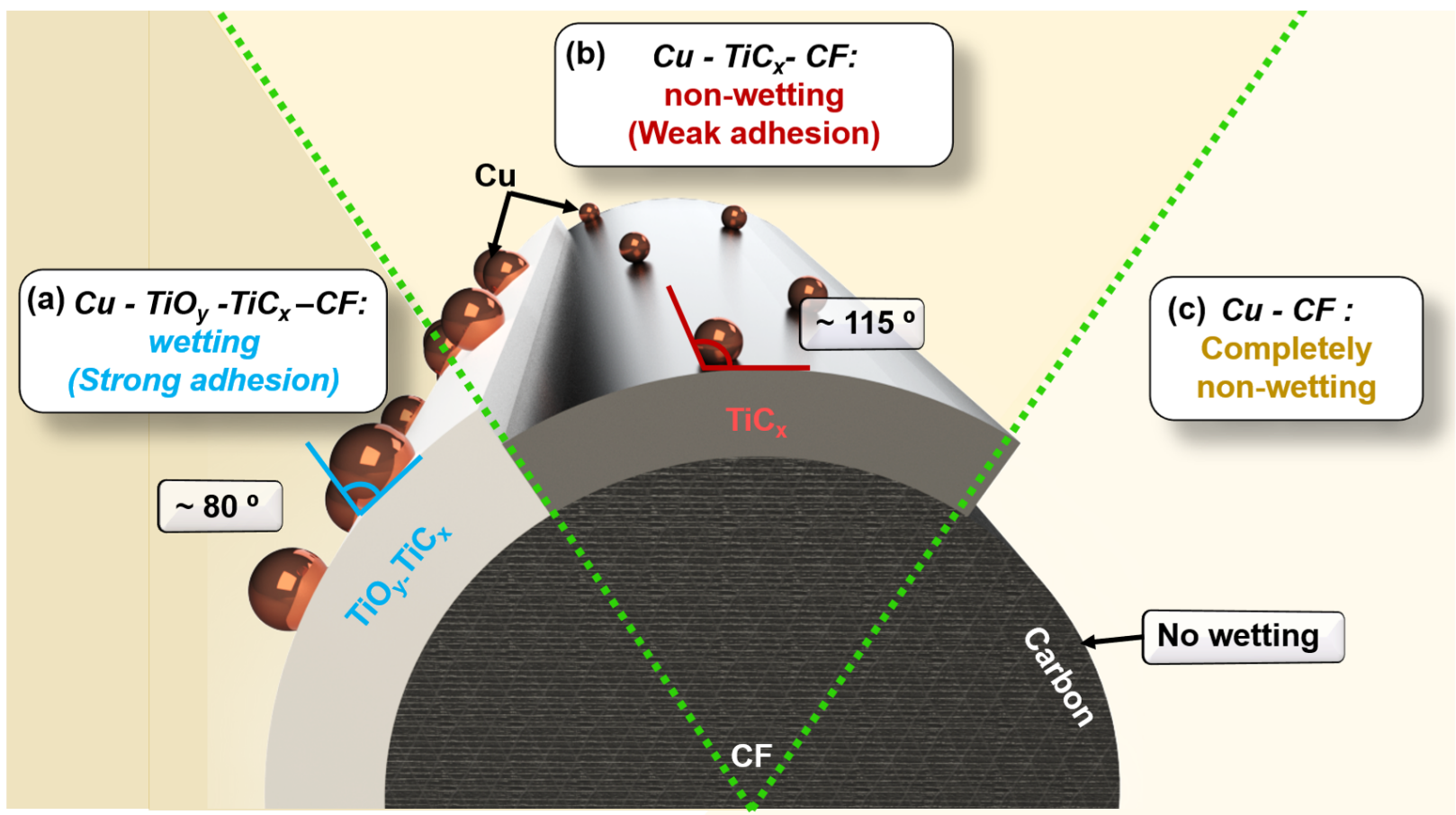




\title{
Design of Tailored Oxide-Carbide Coating on Carbon Fibers for a Robust Copper/Carbon Interphase
}

\author{
Loic Constantin, ${ }^{1,2, *}$ Lisha Fan, ${ }^{2,+}$ Qiming Zou, ${ }^{2}$ Benjamin Thomas, ${ }^{1}$ Jérôme Roger, ${ }^{3}$ \\ Jean-Marc Heinz, ${ }^{1}$ Catherine Debiemme-Chouvy, ${ }^{4}$ Bruno Mortainge, ${ }^{5}$ Yong Feng Lu, ${ }^{2, *}$ and \\ Jean-Francois Silvain ${ }^{1,2, *}$
}

${ }^{1}$ CNRS, Univ. Bordeaux, Bordeaux INP, ICMCB, UMR 5026 F-33608 Pessac, France.

${ }^{2}$ Department of Electrical and Computer Engineering, University of Nebraska-Lincoln, Lincoln, NE, 68588.

${ }^{3}$ Université de Bordeaux, Laboratoire des Composites Thermo Structuraux - LCTS 3 allée de la Boétie, F-33600 Pessac Cedex, France.

${ }^{4}$ Laboratoire Interfaces et Systèmes Electrochimiques - LISE, UMR 8235, CNRS, Sorbonne Université, 4 place Jussieu F-75252 Paris Cedex, France.

${ }^{5}$ Département Générale de l'Armement - DGA/DS/Mission pour la Recherche et l'Innovation Scientifique, 92221 Bagneux, France.

* Corresponding Authors, Jean-Francois Silvain: jean-francois.silvain@icmcb.cnrs.fr and Yong Feng Lu: ylu2@unl.edu 
Abstract: The lack of robust interphases between carbon and most metals prevent the exploration of the full scope potential of carbon-based metal matrix composites. Here, we demonstrated a scalable and straightforward way to produce strong interphase between copper $(\mathrm{Cu})$ and carbon fibers $(\mathrm{CFs})$ by designing a tailored titanium oxide-carbide coating $\left(\mathrm{TiO}_{\mathrm{y}}-\mathrm{TiC}_{\mathrm{x}}\right)$ on CFs in a molten salt process. The oxide-carbide composition in the graded layer strongly depends on the coating temperature $\left(800-950{ }^{\circ} \mathrm{C}\right)$. A coating with a high $\mathrm{TiO}_{\mathrm{y}}$ content obtained at a low coating temperature $\left(800^{\circ} \mathrm{C}\right)$ contributes to better molten-Cu wetting and strong adhesion energy between $\mathrm{CFs}$ and $\mathrm{Cu}$ during a subsequent exposure at $1200{ }^{\circ} \mathrm{C}$. The $\mathrm{Cu}$ wetting angle for the $\mathrm{TiO}_{\mathrm{y}}-\mathrm{TiC}_{\mathrm{x}}-\mathrm{CF}$ sample obtained at $800^{\circ} \mathrm{C}$ was $\sim 80^{\circ} \pm 5^{\circ}$ with a $\mathrm{Cu}$ surface coverage of $\sim 50 \%$ versus $\sim 115^{\circ}$ and $\sim 10 \%$ for the $\mathrm{TiC}_{\mathrm{x}}-\mathrm{CF}$ sample made at $950{ }^{\circ} \mathrm{C}$. The kinetic analysis of the coating process step by step suggests a growth rate limited by the mass-transfer through the coated layer. This method provides a novel approach to improve the thermal conductivity of $\mathrm{Cu} / \mathrm{C}$ composite for thermal management applications.

\section{INTRODUCTION}

Metal matrix composites (MMC) need robust interphases to enhance mechanical adhesion and tailor the overall properties of the resultant composite [1]. The formation of interphases is particularly crucial in composites comprised of chemically and thermomechanically dissimilar compositions [2,3]. Copper $(\mathrm{Cu})$ reinforced carbon fibers $(\mathrm{CFs})$ is an excellent example of $\mathrm{MMC}$ with weak interfacial bonding. This MMC is of particular interest in thermal management, as a next-generation heat sink material [4]. Solid $\mathrm{Cu}$ alone is limited by fatigue failure due to cyclical thermal stresses. Adding $\mathrm{CFs}$ to reinforce $\mathrm{Cu}$ offers one advantage of combining the high strength, low fatigue failure of CFs with the high thermal conductivity of $\mathrm{Cu}\left(400 \mathrm{~W} \cdot \mathrm{m}^{-1} \mathrm{~K}^{-1}\right)$. Nevertheless, a simple $\mathrm{Cu}-\mathrm{CFs}$ composite suffers from poor $\mathrm{Cu}$ wettability on carbon (C) due to 
the lack of chemical affinity [5]. The lack of affinity is more significant when molten metal is in direct contact with the carbon reinforcement such as in gas pressure infiltration, squeeze casting, stir casting, or more recently laser printing [6-8].

Extensive experimental and theoretical work has been devoted on the interphase engineering to improve $\mathrm{CF}-$ reinforced $\mathrm{Cu}$ matrix composite $[9,10]$. One approach has been to alloy the metal with carbide-forming elements (e.g., titanium (Ti), zirconium ( $\mathrm{Zr})$, chromium $(\mathrm{Cr})$, and boron (B)) [11-13]. However, the properties are severely degraded due to inhomogeneous dispersion of the alloying elements at the interface [14-16]. The second approach of considerable interest is to coat the carbon reinforcement with carbides [17,18]. Titanium carbide (TiC) offers strong oxidation resistance, high mechanical strength, excellent chemical stability, and low density, making it a right candidate as interphase [19]. However, it has been reported that $\mathrm{TiC}$ does not wet thoroughly molten $\mathrm{Cu}$ (contact angle $>115^{\circ}$ ), resulting in poor adhesion to TiC surfaces [20].

This paper reports a third approach, which consists of creating a graded titanium oxide - carbide $\left(\mathrm{TiO}_{\mathrm{y}}-\mathrm{TiC}_{\mathrm{x}}\right)$ coating on $\mathrm{CFs}$ using a molten-salt method to tailor the $\mathrm{Cu}$ - Carbon interphase. Molten-salt synthesis provides a versatile and efficient way to produce transition metal carbides at relatively low temperatures in short time frames. The salt acts as a solvent to dissolve the metal powders and, therefore, enhance the Ti mass transport to the CF surfaces $[21,22]$. The research results showed that the presence of a thin $\mathrm{TiO}_{\mathrm{y}}$ outer layer on the $\mathrm{TiC}_{\mathrm{x}}$ coating improves the wettability of molten $\mathrm{Cu}$ (Figure 1). The interfacial wetting angle of $\mathrm{Cu}$ on the $\mathrm{TiO}_{\mathrm{y}}-\mathrm{TiC}_{\mathrm{x}^{-}}$ coated CFs reduced to be $\sim 80 \pm 5^{\circ}$, thus offering a significant improvement over $\mathrm{TiC}_{\mathrm{x}}$ alone. The rate of elemental diffusion and the nature of the $\mathrm{Cu}-\mathrm{TiO}_{\mathrm{y}}$ and $\mathrm{Cu}-\mathrm{TiC}_{\mathrm{x}}$ bonding were examined. The influence of the coating temperature and time on the $\mathrm{TiO}_{\mathrm{y}}-\mathrm{TiC}_{\mathrm{x}}$ microstructures and the chemical compositions of the coatings were quantified. Finally, the process kinetics showed that 
the mass-transfer limits the rate of $\mathrm{TiC}_{\mathrm{x}}$ formation through the coated layer; the effective diffusivities governing the process were determined.

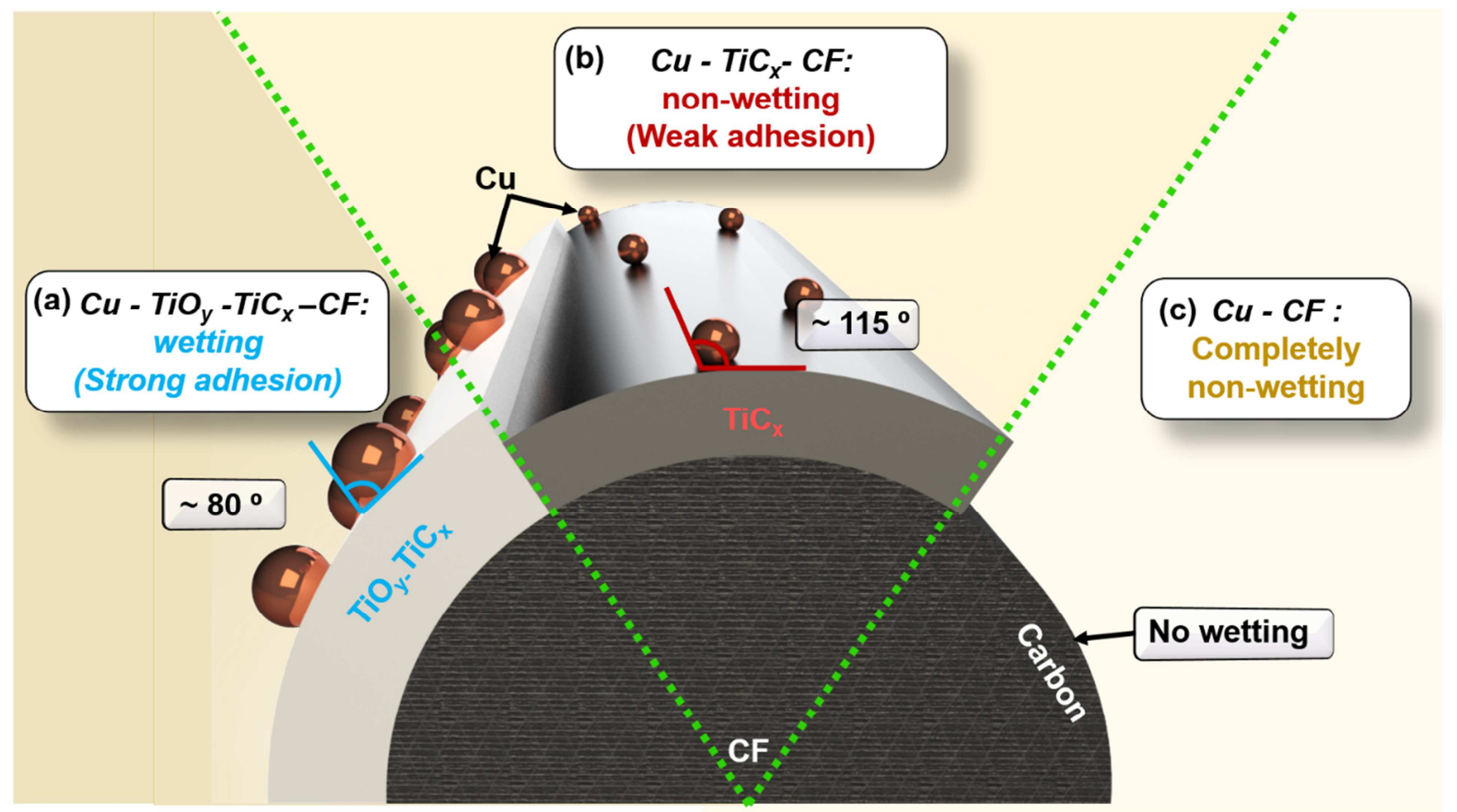

Figure 1. Schematic illustration of $\mathrm{Cu}$ wetting behavior measured by contact angles and droplet coverage on CFs with different interphases: (a) $\mathrm{TiO}_{\mathrm{y}}-\mathrm{TiC}_{\mathrm{x}}$, (b) $\mathrm{TiC}_{\mathrm{x}}$, and (c) bare $\mathrm{CF}$.

\section{EXPERIMENTAL SECTION}

\subsection{Preparation of coatings on CFs.}

The synthesis of the carbide coatings was carried out by a molten-salt process, illustrated schematically in Figure 2. First, CFs (Mitsubishi Chemical DIALEAD ${ }^{\mathrm{TM}}$ K223HM) were mixed with a potassium chloride (KCl) (GPR Rectapur ${ }^{\circledR}$ 99\%) salt and metallic Ti powder (Ti 99.5\%, mean diameter $40 \mu \mathrm{m}$ ) at a molar ratio of $\mathrm{KCl}: \mathrm{C}: \mathrm{Ti}=0.64: 1: 0.125$. The mixture was then placed in alumina $\left(\mathrm{Al}_{2} \mathrm{O}_{3}\right)$ crucible and heated in a tube oven filled with flowing argon (Ar) gas. The coating temperature varied from 800 to $950 \square$ for times of up to $5 \mathrm{~h}$. These coating conditions were chosen based on Lui et al. study [23]. After cooling down, the crucible was immersed in a 
boiling distilled water $\left(\sim 100^{\circ} \mathrm{C}\right)$ until the salt was fully dissolved. Finally, the coated CFs were filtered from the solution, flushed with deionized (DI) water, and air-dried in an oven at $60{ }^{\circ} \mathrm{C}$ for $1 \mathrm{~h}$. The filtration dissolution/filtering process was repeated three times; the coated CF product yield is $\sim 95 \%$.

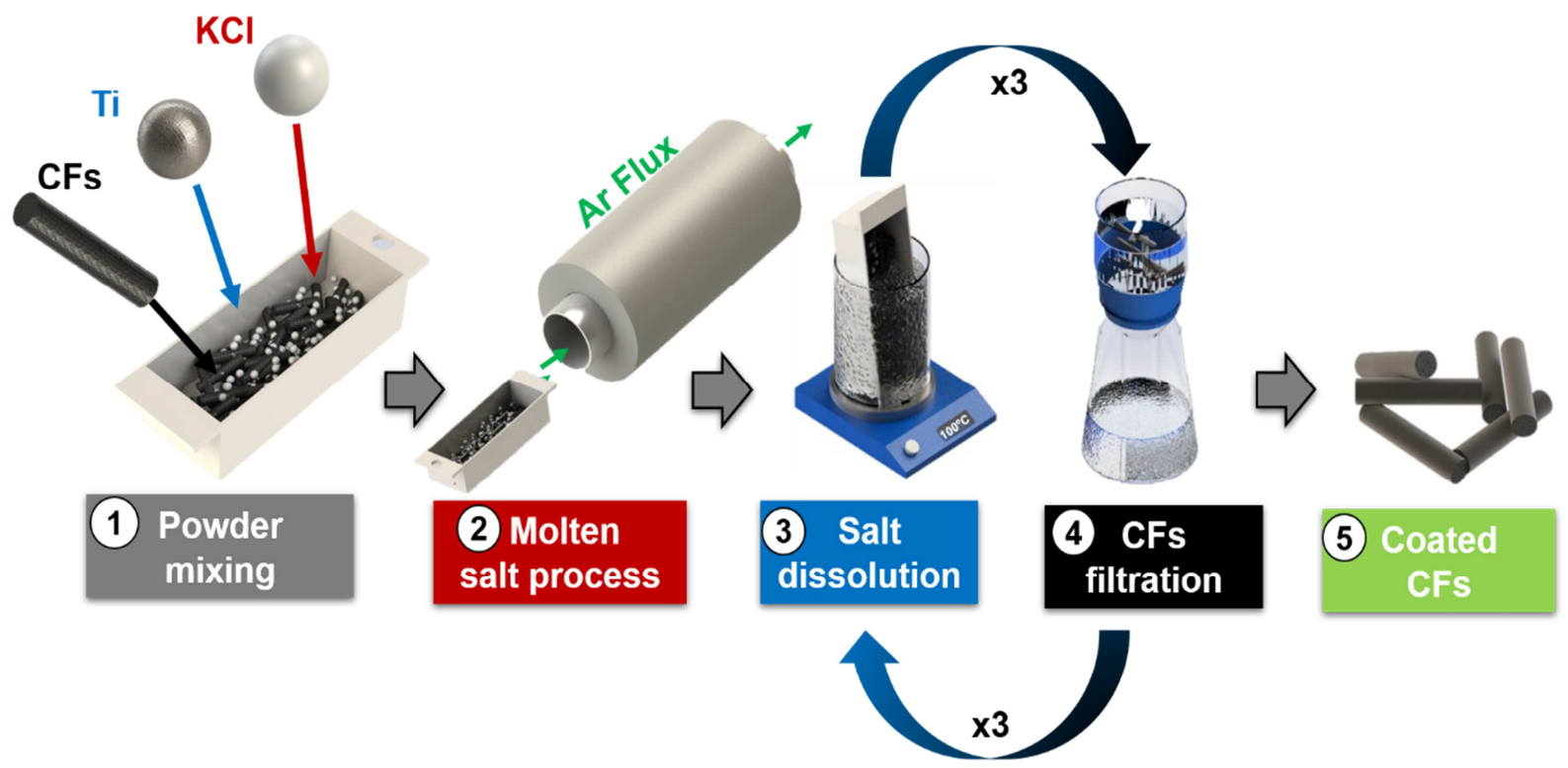

Figure 2. Schematic illustration of the molten-salt process for preparing TiC-based coatings on CFs.

\subsection{Wettability analysis.}

The wettability of molten $\mathrm{Cu}$ (melting point $1085^{\circ} \mathrm{C}$ ) on the coated $\mathrm{CFs}$ was investigated using an approximate equal-molar mixture of $0.2 \mathrm{~g}(\sim 0.017 \mathrm{~mol})$ of coated CFs with $1.2 \mathrm{~g}(0.019 \mathrm{~mol})$ of dendritic $\mathrm{Cu}$ powder $(35 \mu \mathrm{m}$, ECKA Granules Germany $\mathrm{CmbH})$. The mixture was placed in an $\mathrm{Al}_{2} \mathrm{O}_{3}$ crucible with a carbon paper liner to prevent reaction between the $\mathrm{Cu}$ powder and the crucible. The crucible was put into a tube oven filled with flowing argon gas and heated to 1200 ${ }^{\circ} \mathrm{C}$ with a rate of $10{ }^{\circ} \mathrm{C} / \mathrm{min}$. The crucible was held for $10 \mathrm{~min}$ and then cooled to room temperature at a rate of $15{ }^{\circ} \mathrm{C} / \mathrm{min}$. Contact angles between the $\mathrm{CFs}$ and the $\mathrm{Cu}$ droplets were 
determined using scanning electron microscopy (SEM) and cross-sectional images of resinencased and polished CFs.

\subsection{Quenching tests.}

Rapid thermal quenching of the molten salt in the ambient air was used to terminate the coating process at intermediate stages. This enabled the study of the $\mathrm{TiC}$ formation, including $\mathrm{Ti}$ dissolution, diffusion, and reaction with CFs. The quenching tests were performed by heating the powder mixture to 800 and $950{ }^{\circ} \mathrm{C}$ for 0.5 and $5 \mathrm{~h}$, respectively. The hot crucible was then rapidly quenched in the air at a cooling rate of about $500{ }^{\circ} \mathrm{C} / \mathrm{min}$, resulting in $\mathrm{KCl}\left(\mathrm{m}_{\mathrm{p}}=770^{\circ} \mathrm{C}\right)$ solidification in less than $20 \mathrm{~s}$. A piece of the solidified KCl-CFs-Ti sample was embedded in a polyphenolic resin, and mechanically dry polished for SEM analyses.

\subsection{The growth rate of the TiC layer.}

The diffusivity and associated activation energy were measured by mixing $\mathrm{KCl}, \mathrm{CFs}$, and $\mathrm{Ti}$ with a molar ratio of $\mathrm{KCl}: \mathrm{CFs}: \mathrm{Ti}=0.642: 1: 0.238$. Both coating times and temperatures were varied between 1 to $5 \mathrm{~h}$ at processing temperatures of $800,850,900$, and $950{ }^{\circ} \mathrm{C}$, respectively. After the reaction, the coated CFs were washed and dried as described earlier. The coated CFs were then embedded in a polyphenolic resin and polished for SEM analyses.

\subsection{Characterization methods.}

Morphological and microstructural characterization was performed using an SEM (VEGA II SBH, TESCAN). Crystal structures and chemical phases were identified by X-ray diffraction (XRD) (PANalytical X'pert PRO MPD, $\lambda=1.5405 \AA$ ). The stoichiometry of $\mathrm{TiC}_{\mathrm{x}}$ was estimated by calculating the lattice parameters from the XRD diffractograms via the Le-Bail method [24] using the FullProf Suite. Auger electron spectroscopy (AES) (Auger VG Scientific Microlab 
310F) and X-ray photoelectron spectroscopy (XPS, Thermo Electron K-alpha photoelectron spectrometer, $\mathrm{Al} \mathrm{K} \alpha$ excitation) were used to determine the elemental and chemical compositions. The AES sputtering time was converted to a depth profile by measuring the layer removal depth using SEM. Grain morphology, orientation, and size were evaluated using electron backscatter diffraction (EBSD).

\section{RESULTS AND DISCUSSION}

\subsection{Effect of temperature on $\mathrm{TiC}_{x}$ coating composition and morphology}

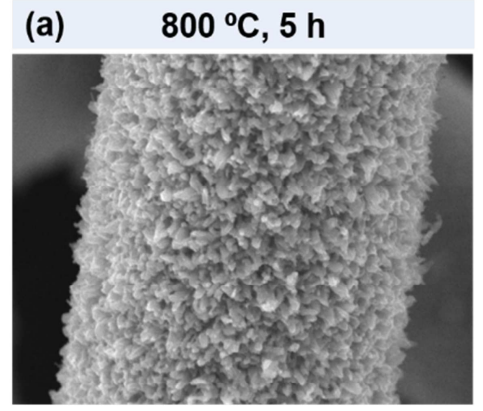

$900^{\circ} \mathrm{C}, 5 \mathrm{~h}$

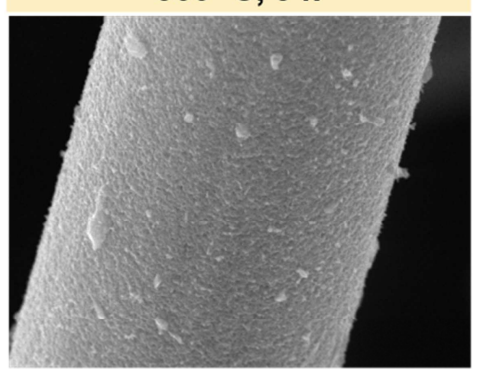

$850^{\circ} \mathrm{C}, 5 \mathrm{~h}$

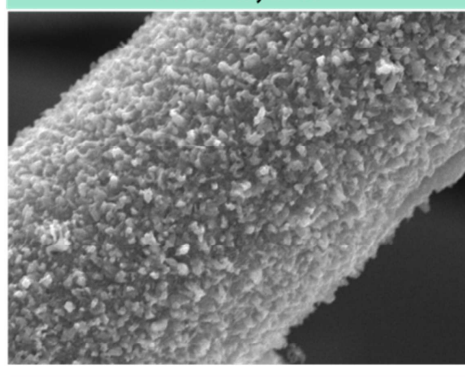

$950^{\circ} \mathrm{C}, 5 \mathrm{~h}$

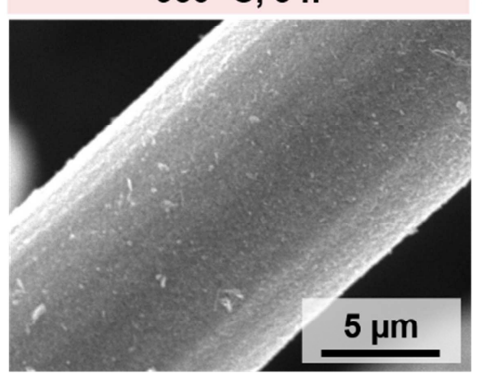

(b)

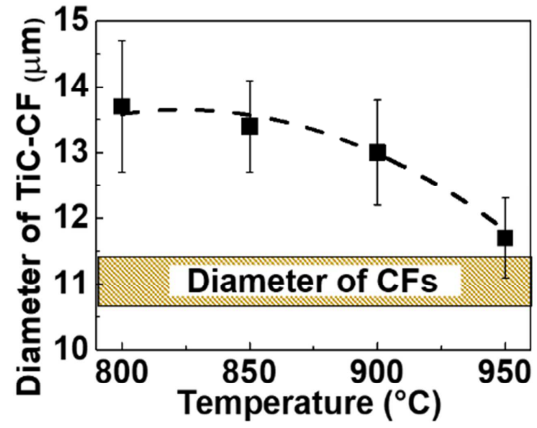

(c)

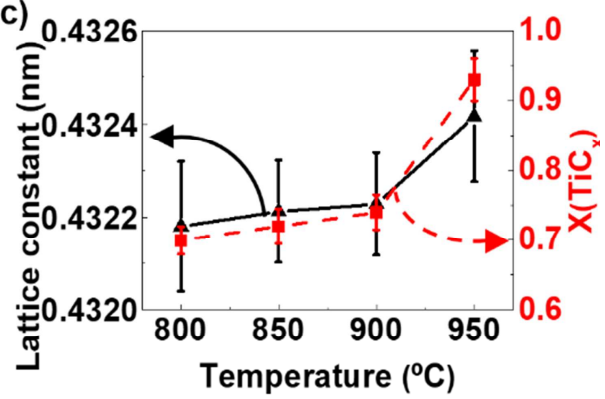

Figure 3. Influence of the coating temperature, ranging from 800 to $950{ }^{\circ} \mathrm{C}$, on the layer morphology and composition, a) $\mathrm{SEM}$ micrographs, b) $\mathrm{TiC}_{\mathrm{x}}-\mathrm{CF}$ diameter vs. coating temperature, and c) measured lattice constant and associated $\mathrm{C} / \mathrm{Ti}$ atomic ratio vs. temperature.

The effects of reaction temperature on the coating morphology and structure are shown in Figure 3. In this study, the reaction time was $5 \mathrm{~h}$ at temperatures ranging from 800 to $950{ }^{\circ} \mathrm{C}$. The SEM micrographs of the coatings (Figure 3 (a)) display a dramatic change in the morphology with 
different temperatures. Specifically, at 800 and $850{ }^{\circ} \mathrm{C}$, the surfaces appeared to be a porous collection of particle-like features with open, interconnected porosity of more than $50 \%$ (pore sizes from 300 to $1000 \mathrm{~nm}$ ). This suggests the growth was from reactive C surface sites with little consolidation by surface-diffusion-driven sintering. Both Xiaoguang Liu et al. [23] and Qian Liu et al. [25] have observed similar porous coatings formed by Ti reaction with carbon substrates at $750{ }^{\circ} \mathrm{C}$ in a potassium chloride:lithium chloride $(\mathrm{KCl}: \mathrm{LiCl})$ salt and at $900{ }^{\circ} \mathrm{C}$ in a lithium chloride:potassium chloride:potassium fluoride ( $\mathrm{LiCl}: \mathrm{KCl}: \mathrm{KF})$ salt, respectively.

In contrast, coatings at 900 and $950^{\circ} \mathrm{C}$ have far fewer and smaller pores and appear almost fully consolidated. In these cases, the temperature is sufficiently high that localized differences in surface reactivity become less critical for determining the growth morphology. Moreover, the possibility of sintering driven by surface diffusion would be more significant. Both effects, individually or combined, could explain the dense coating obtained at high temperatures. Others have reported consolidated coatings at temperatures above $900{ }^{\circ} \mathrm{C}$ in different salts $[18,26]$.

Scanning electron micrographs show that the diameters of the reacted fibers (i.e., core CFs plus coated layers) decreased as the temperature increased, as plotted in Figure 3 (b). In other words, the growth of porous coatings at 800 and $850{ }^{\circ} \mathrm{C}$ caused the resulting diameter to increase from $\sim 11$ (i.e., original CFs) to $13 \mu \mathrm{m}$ (i.e., coated CFs). In contrast, the layer obtained at $950{ }^{\circ} \mathrm{C}$ was almost fully dense and increased the product diameter by only $\sim 0.5 \mu \mathrm{m}$ from the original CF diameters. The coating porosity was estimated from a mass balance of the reactants, as given in the Supplementary Information (SI), Section 2 . The fully dense ( $0 \%$ porosity) coating thickness was predicted to be $0.55 \mu \mathrm{m}$ via the mass balance calculation, suggesting an outer fiber diameter of $11.45 \mu \mathrm{m}$. This is in reasonable agreement with the outer diameter of $11.6 \mu \mathrm{m}$ observed for fibers reacted at $950{ }^{\circ} \mathrm{C}$ (Figure 3 (b)) and supported the observations that the porosity was low 
(<10\%). Similarly, the coating prepared at $800^{\circ} \mathrm{C}$ has a measured outer diameter of $\sim 13.5 \mu \mathrm{m}$, suggesting a porosity of $\sim 65 \%$, again in agreement with the observations.

In addition to the surface morphology, XRD was performed at each processing temperature to quantify the product phase composition (Figure $\mathbf{S 1}(\mathbf{c})$ ). The relationships between the $\mathrm{TiC}_{\mathrm{x}}$ lattice parameters and the coating temperature were determined from XRD data using the LeBail method (Figure 3 (c)). [24] Further details from the analyses are provided in Figure S2. A correlation between the $\mathrm{TiC}_{\mathrm{x}}$ lattice parameters and the chemical stoichiometry was established to determine the change in the coating stoichiometry as a function of the temperature [27-29]. The results show, within the experimental errors, that the stoichiometry is $\sim \mathrm{TiC}_{0.73}$ for the product formed between 800 to $900{ }^{\circ} \mathrm{C}$. On the other hand, the coating produced at $950{ }^{\circ} \mathrm{C}$ has a higher carbon content with a stoichiometry of $\sim \mathrm{TiC}_{0.93}$. One explanation for the change is that the $\mathrm{Ti}$ and $\mathrm{C}$ diffusivities were both greater at higher temperatures and thus tended to form a more reacted coating. This explanation is supported in part by the measurements of the self-diffusion coefficients of $\mathrm{C}$ and $\mathrm{Ti}$ in $\mathrm{TiC}$ as a function of the temperature [30-32], as well as results from the process kinetics, described later in this work.

\subsection{Interphase elemental composition $\left(\mathrm{TiC}_{x} \mathrm{vs} . \mathrm{TiO}_{y}-\mathrm{TiC}_{x}\right)$}

In the previous section, it was shown that the salt bath temperature influenced the morphology and stoichiometry of the $\mathrm{TiC}_{\mathrm{x}}$ coating. This section describes how a combination of SEM, AES, and XPS was used to quantify the chemical compositions of the coated layers produced at the low $\left(800{ }^{\circ} \mathrm{C}\right)$ and high $\left(950{ }^{\circ} \mathrm{C}\right)$ temperatures. The AES compositional mapping in Figure 4 shows the presence of not only $\mathrm{TiC}_{\mathrm{x}}$ on the $\mathrm{CF}$ surfaces but also an outer layer of $\mathrm{TiO}_{\mathrm{y}}$. The elemental analyses at different depths of the coatings prepared at $800{ }^{\circ} \mathrm{C}$ show a thin $\mathrm{TiO}_{\mathrm{y}}$ outer layer that extends to a depth of $\sim 20 \%$ of the coating thickness. Based on the results in Figure 4 
(a), the width of the $800^{\circ} \mathrm{C}$ coating is about $1.2 \mu \mathrm{m}$, suggesting an outer partially oxidized layer of $250 \mathrm{~nm}$. In contrast, the coatings prepared at $950{ }^{\circ} \mathrm{C}$ were significantly denser with a thickness of $\sim 0.30 \mu \mathrm{m}$ (Figure 4 (b)) and a $\mathrm{TiO}_{\mathrm{y}}$ outer layer of $<5 \mathrm{~nm}$. In other words, the $950{ }^{\circ} \mathrm{C}$ coating is essentially $100 \% \mathrm{TiC}_{\mathrm{x}}$. Supplementary details of the AES are provided in Figure $\mathbf{S 3}$.
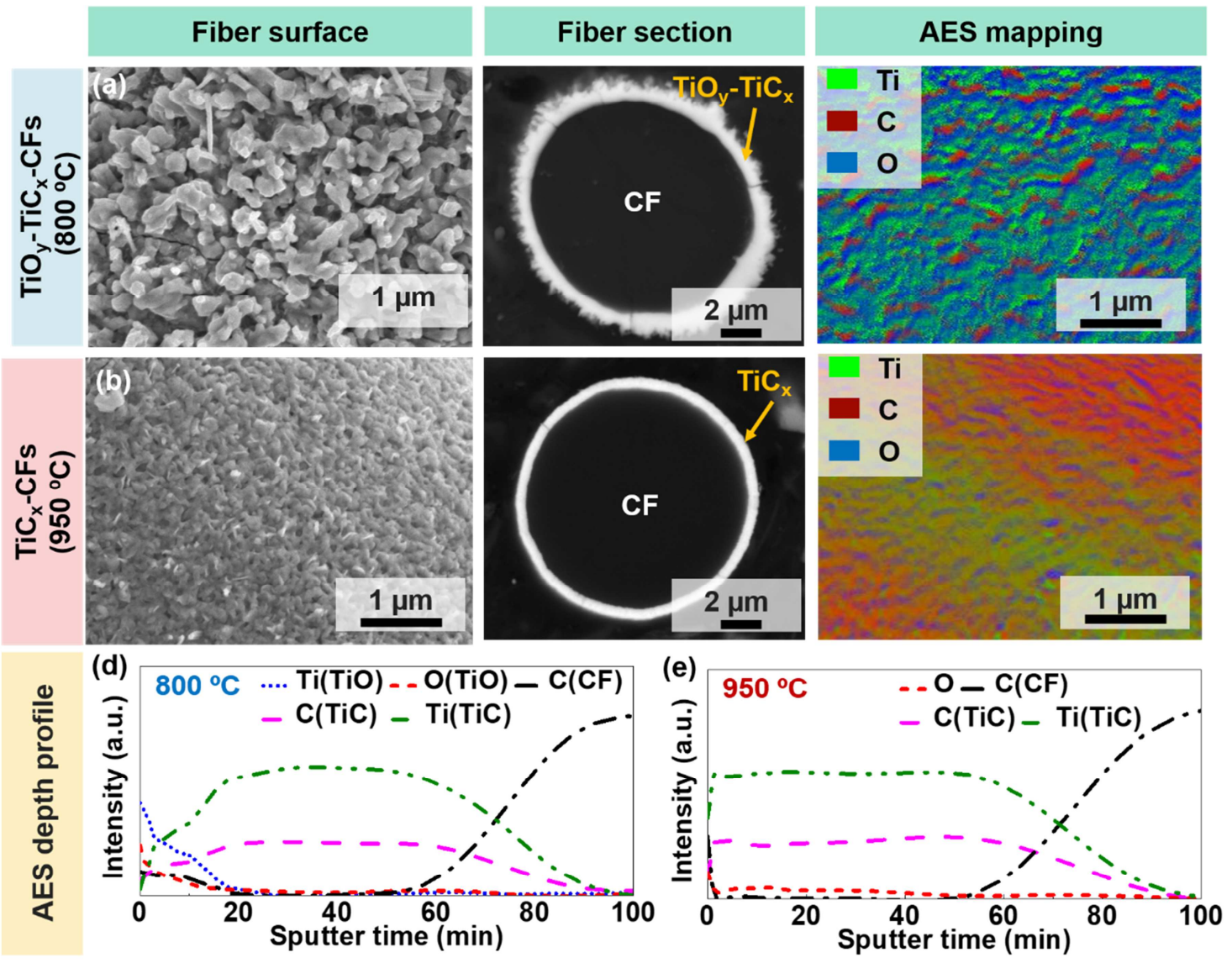

Figure 4. Surface morphology, cross-sectionanl and AES maps of the coated CFs prepared at (a) 800 and (b) $950{ }^{\circ} \mathrm{C}$, respectively; and AES depth profiles of the coated CFs prepared at (d) 800 and (e) $950^{\circ} \mathrm{C}$, respectively.

Additionally, XPS was used to quantify the influence of the coating temperature on the graded oxide-carbide ratio. The $\mathrm{C}-\mathrm{C}$ peaks observed at the binding energy (BE) of $284.6 \mathrm{eV}$ in the $\mathrm{C} 1 \mathrm{~s}$ spectra, originated from the unreacted $\mathrm{CFs}$. The $\mathrm{O} 1 \mathrm{~s}$ spectrum shows an $\mathrm{O}=\mathrm{C}$ peak $(\mathrm{BE} \sim 530$ 
$\mathrm{eV})$ with an $\mathrm{O}-\mathrm{Ti}$ shoulder $(\mathrm{BE} \sim 531 \mathrm{eV})$; and the Ti 2p spectra shows two types of bonding configurations: Ti-C and Ti-O, respectively (Figure S4). Standard spectral analysis procedures were used to separate the XPS Ti $2 p$ spectra into contributions from $\mathrm{TiC}_{\mathrm{x}}$ and $\mathrm{TiO}_{\mathrm{y}}($ Table $\mathbf{1})$. The results display the same trend as the AES results: the distributions of surface Ti bonded as Ti-C vs. Ti-O strongly depend on the coating temperature. The results demonstrate $\sim 50 \%$ of the surface $\mathrm{Ti}$ was bonded as $\mathrm{TiO}_{\mathrm{y}}$ at $800{ }^{\circ} \mathrm{C}$ with only $\sim 10 \%$ at $950{ }^{\circ} \mathrm{C}$.

Table 1. XPS quantitative analyses using peak integration.

\begin{tabular}{|c|c|c|c|c|c|c|}
\hline Sample & $\mathrm{C}_{\text {tot }}($ at $\%)$ & $\mathrm{C}_{\mathrm{TiC}_{\mathrm{x}}}(\mathrm{at} \%)$ & $\mathrm{Ti}_{\text {tot }}$ (at \%) & $\mathrm{Ti}_{\mathrm{TiO}_{\mathrm{y}}}$ (at \%) & $\mathrm{Ti}_{\mathrm{TiO}_{\mathrm{y}}}(\%)$ & $\mathrm{Ti}_{\mathrm{TiC}_{\mathrm{x}}}(\%)$ \\
\hline $\begin{array}{c}\mathrm{TiO}_{\mathrm{y}}-\mathrm{TiC}_{\mathrm{x}}-\mathrm{CFs} \\
\left(800^{\circ} \mathrm{C}\right)\end{array}$ & 70.8 & 7.3 & 14.6 & 7.3 & 50 & 50 \\
\hline $\begin{array}{l}\mathrm{TiC}_{\mathrm{x}}-\mathrm{CFs} \\
\left(950^{\circ} \mathrm{C}\right)\end{array}$ & 70.8 & 13.2 & 14.5 & 1.5 & 10.3 & 89.7 \\
\hline
\end{tabular}

The presence of $\mathrm{TiO}_{\mathrm{y}}$ was unexpected as the $\mathrm{Ti}+\mathrm{CF}$ reaction was carried out in a flowing Ar gas. A possible explanation is that the $\mathrm{TiO}_{\mathrm{y}}$ formed during boiling water $\left(\sim 100{ }^{\circ} \mathrm{C}\right)$ dissolution of the $\mathrm{KCl}$ salt at the end of the process. Naturally, the effective oxidation depth (via both the AES and XPS) would be larger for the highly porous coatings obtained at $800{ }^{\circ} \mathrm{C}$ simply due to the enhanced water penetration. Also, the coatings obtained at $800^{\circ} \mathrm{C}$ have a more stoichiometrically Ti-rich layer $\left(\mathrm{TiC}_{0.73}\right.$, see the previous section), suggesting more reactive, non-bonded $\mathrm{Ti}$ sites that could be oxidized. In contrast, the highly consolidated and essentially pure $\mathrm{TiC}_{\mathrm{x}}$ coatings formed at $950{ }^{\circ} \mathrm{C}$ (i.e., $\mathrm{TiC}_{0.93}$ ) would encounter much less water penetration and, thus, less oxidation.

\subsection{Cu wettability and interphase surface energy}


To establish the role of a graded $\mathrm{TiO}_{\mathrm{y}}-\mathrm{TiO}_{\mathrm{x}}$ coating to tailor the interfacial bonding between $\mathrm{Cu}$ and $\mathrm{C}$, we prepared two types of $\mathrm{CFs}$ coated with a high and a low concentration of oxide content, respectively. The contact angles (wettability) of $\mathrm{Cu}$ on coated CFs prepared at 800 , and $950{ }^{\circ} \mathrm{C}$ were measured, and the well-known Young-Dupre equation was used to estimate the adhesion energy:

$$
E_{S L}=\gamma_{L V}(1+\cos \theta)
$$

where $E_{s l}$ is the energy (work) of adhesion $\left(\mathrm{mN}^{-1} \mathrm{~m}^{-1}\right), \gamma_{v v}$ is the liquid/vapor surface energy (tension) $\left(\mathrm{mN} \cdot \mathrm{m}^{-1}\right)$, which has been reported to be $\gamma_{C u}=1257-0.2(T-1356)$ for $\mathrm{Cu}$ [33], and $\theta$ is the equilibrium contact angle. The results show that $\mathrm{Cu}$ does not wet $\mathrm{CFs}$ due to the low surface energy of the material (supplementary Figure S5). This is in agreement with the prior work reporting a contact angle of $145^{\circ}$ [34]. Creation of a TiC coating on CFs has shown to reduce the $\mathrm{Cu}$ contact angle to $115^{\circ}$ [35], but the coating is still nonwetting and is confirmed in this study for a coating prepared at $950{ }^{\circ} \mathrm{C}$ (Figures 5 (a) and (c)). In contrast, the coated CFs prepared at $800^{\circ} \mathrm{C}$, with $\mathrm{TiO}_{\mathrm{y}}$ layer (Figures 5 (b) and (c)), show a $\mathrm{Cu}$ wetting angle of $\sim 80^{\circ}( \pm$ $5^{\circ}$ ) and thus is a good wetting surface. In other words, there was sufficient oxide on the outer surface to increase the coating surface energy. For comparison, data reported for a $\mathrm{Cu}$ wetting angle of $80^{\circ}$ on $\mathrm{TiO}$ is also included (Figure 5 (c)) [36].

Recall that the $\mathrm{TiO}_{\mathrm{y}}-\mathrm{TiC}_{\mathrm{x}}$ coatings prepared at $800{ }^{\circ} \mathrm{C}$ are highly porous (Figure $5(\mathbf{a})$ ). However, after heating at $1200{ }^{\circ} \mathrm{C}$ during the $\mathrm{Cu}$ wetting tests, the surface fully consolidated (Figure 5 (d) and (f). The surface coverage by $\mathrm{Cu}$ droplets on the coated and bare CFs (Figure S6) was computed and compared with the fraction of $\mathrm{TiO}_{\mathrm{y}}$ in the coatings (Figure $5(\mathbf{h})$ ). The $\mathrm{Cu}$ coverage was fivefold greater on $\mathrm{TiO}_{\mathrm{y}}-\mathrm{TiC}_{\mathrm{x}} \mathrm{CFs}$ compared to the $\mathrm{TiC}_{\mathrm{x}} \mathrm{CFs}$ and. As expected, the $\mathrm{Cu}$ coverage of the bare (unreacted) $\mathrm{CFs}$ was negligible. The transition from low to high 
wettability correlates perfectly with the steady increase of $\mathrm{TiO}_{\mathrm{y}}$ content in the $\mathrm{TiC}_{\mathrm{x}}$ coatings. The improved $\mathrm{Cu}$ wettability achieved with the graded $\mathrm{TiO}_{\mathrm{y}}-\mathrm{TiC}_{\mathrm{x}}$ coatings developed in this work suggests a rather simple processing pathway for producing robust interphase in metal-carbon composites. The simplicity and cost-effectiveness of a molten salt process have been extensively used to prepare a $\mathrm{TiC}$ interphase in $\mathrm{Cu} / \mathrm{C}$ composites. Often high coating temperature is employed, resulting in the formation of a pure TiC layer [17,25]. As demonstrated previously, $\mathrm{TiC}$ is known as a nonwetting element on molten $\mathrm{Cu}$ with a contact angle of $115^{\circ}$. The development of a tailored $\mathrm{TiO}_{\mathrm{y}}-\mathrm{TiC}_{\mathrm{x}}$ enables the formation of strong interphase between $\mathrm{Cu}$ and $\mathrm{C}$ in comparison to a pure $\mathrm{TiC}$ layer. The strong interfacial bonding observed in this work between the graded $\mathrm{TiO}_{\mathrm{y}}-\mathrm{TiC}_{\mathrm{x}}$ layer and $\mathrm{Cu}$ will indubitably enhance the interaction between molten $\mathrm{Cu}$ and coated-CFs during the composite fabrication via gas infiltration, stir casting, squeeze casting or more recently, selective laser melting [6,7].

\subsection{The kinetic analysis of the coating formation process}

To further understand the formation process of the graded coating, the molten salt was rapidly quenched at intermediate stages to "freeze" the state of the reaction to examine the intermediate states (Figure S7). Three steps mainly govern the growth process: 1) oxidation-driven dissolution of $\mathrm{Ti}$ particles into the salt $\left(\mathrm{Ti}^{\mathrm{o}}\right.$ to $\left.\left.\mathrm{Ti}^{\mathrm{n}+}\right),[37,38] 2\right)$ diffusion mass transport of $\mathrm{Ti}^{\mathrm{n}+}$ to the surface of the CFs or the $\mathrm{TiC}_{\mathrm{x}}-\mathrm{CF}$ interphase, and 3) $\mathrm{Ti}$ and $\mathrm{C}$ mass transport through the $\mathrm{TiC}_{\mathrm{x}}$ interphase layer and reaction (Figure 6 (a)). In the analyses below, the characteristic times for the three process steps $\left(t_{1}, t_{2}\right.$, and $t_{3}$, respectively) are estimated and compared to determine which is the rate-limiting factor in the coating process.

Regarding Ti dissolution (Step 1), the intermediate state of the Ti particles in the sample that was heated at $800{ }^{\circ} \mathrm{C}$ for $0.5 \mathrm{~h}$ and then quenched was observed. The results show that the original 40 
$\mu \mathrm{m}$ Ti particles had not only begun to dissolve but also showed significant disintegration into small sub-particles (presumably individual Ti grains) (Figure 6 (b)). The computation in SI section 3 shows that the particular dissolution time for an isolated Ti particle in an infinite bath of $\mathrm{KCl}$ is about $\sim 4 \mathrm{~min}$. Thus, it can be concluded that the Ti dissolution rate is fast and rapidly saturates the small $\mathrm{KCl}$ volume used in these tests.
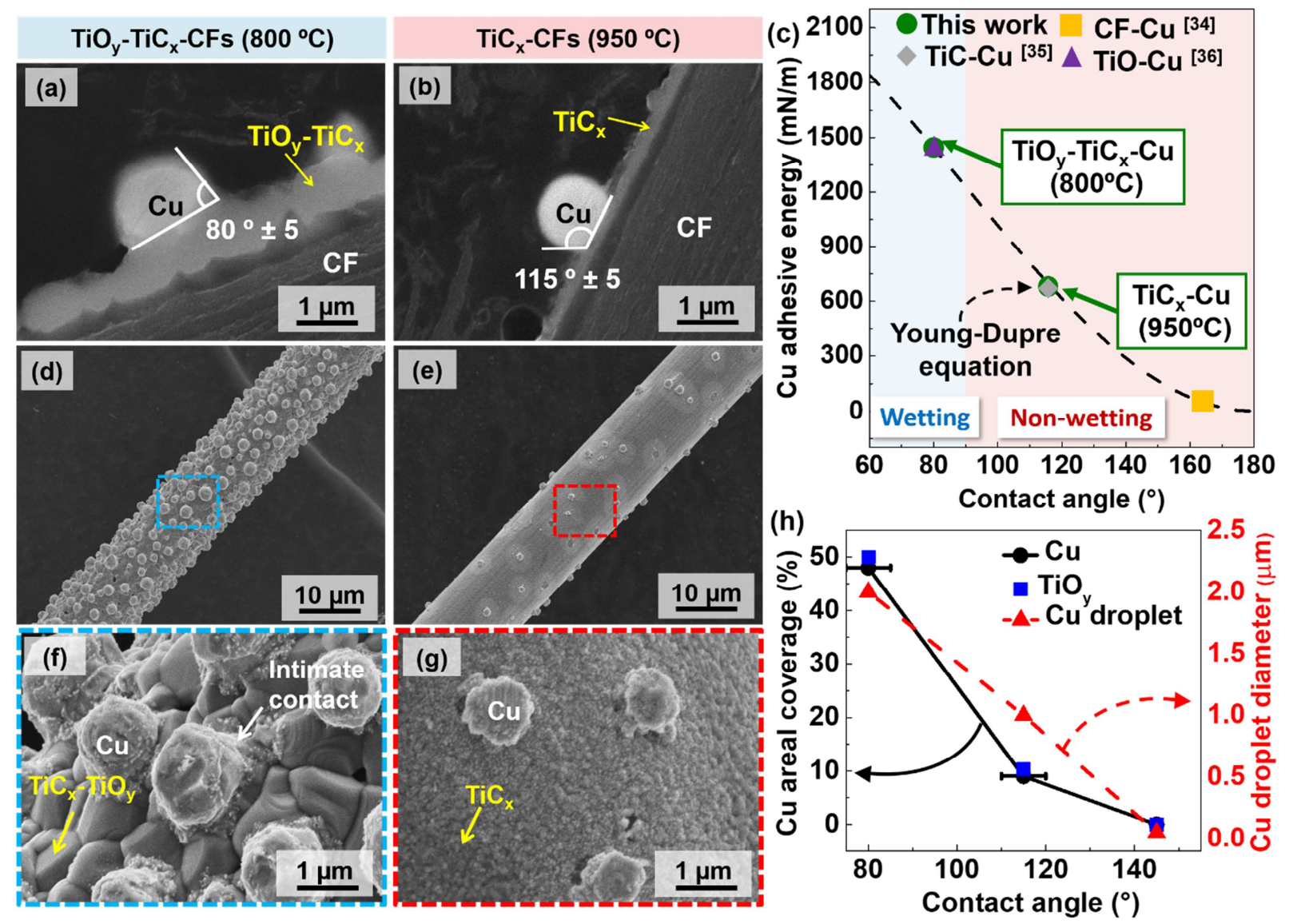

Figure 5. $\mathrm{Cu}$ contact angle measured on $\mathrm{CFs}$ coated with (a) $\mathrm{TiC}_{\mathrm{x}}$ and (b) $\mathrm{TiO}_{\mathrm{x}}-\mathrm{TiC}_{\mathrm{y}}$ prepared at 800 and $950 \square$, respectively. (c) Adhesive (wetting) energy vs. contact angle measured in this work $(\bullet)$ compared to values reported by others for $\mathrm{Cu}$ on $\mathrm{CF}(\boldsymbol{\bullet})$ [34], $\mathrm{TiC}(\bullet)$ [35], and $\mathrm{TiO}$ ( $\Delta$ ) [36], SEM micrographs showing the wetting behavior of $\mathrm{Cu}$ on the coated $\mathrm{CFs}$ prepared at 
(d), (e) 800 and (f), (g) $950 \square$. (h) Measured $\mathrm{Cu}$ areal coverage with the equivalent $\mathrm{TiO}_{\mathrm{y}}$ content and droplet diameter as functions of the wetting angle.

The specific time, $t_{2}$, governing the rate of diffusion mass transport of $\mathrm{Ti}^{\mathrm{n}+}$ to the outer $\mathrm{CFs}$ surface (Step 2) was controlled by the viscosity of the $\mathrm{KCl}$ and the mean distance between the $\mathrm{Ti}^{\circ}$ particles and the CFs. Assuming a statistical average distribution of particles, the mean interparticle distance was, conservatively, smaller than $100 \mu \mathrm{m}$. The approximate time for $\mathrm{Ti}^{\mathrm{n}+}$ to diffuse this distance, $t_{2}$, can be estimated from:

$$
t_{2} \sim \frac{<x>^{2}}{2 D_{T i^{n+}}}
$$

Equation (1) gives an estimated time of $t_{2}<10 \mathrm{~s}$ to diffuse the $100 \mu \mathrm{m}$ (mean $\mathrm{Ti}^{0} / \mathrm{CF}$ interparticle distance). The conclusion from the simple analyses is that both the particle dissolution (Step 1) and $\mathrm{Ti}^{\mathrm{n}+}$ diffusion mass transport (Step 2) are fast with Step 2 being the faster one.

In contrast to the time scale of a few minutes and seconds for Steps 1 and 2, respectively, the time scale for the coating process is on the order of hours. This leads to the logical conclusion that the process step governing the rate of coating formation is Step 3, the diffusion mass transport of $\mathrm{Ti}$, and likely counter diffusion of $\mathrm{C}$, through the interphase coating.

Semi-qualitative analyses of the XRD peak intensities of coated CFs were used to follow step 3, the $\mathrm{TiC}_{\mathrm{x}}$ formation rate versus time at temperatures of 800 and $950{ }^{\circ} \mathrm{C}$, as presented in Figures 6 (c) and (d), respectively. The integrated XRD peak intensities at $800{ }^{\circ} \mathrm{C}$ show the formation of $\mathrm{TiC}_{\mathrm{x}}$ even after $0.5 \mathrm{~h}$, but associated with noticeable Ti peaks (Figure $6(\mathbf{c})$ ). The amount of Ti continuously decreases with the coating time. After $3 \mathrm{~h}$ of reaction, the Ti presents only in trace amounts while none is observed after $5 \mathrm{~h}$ (Figure 6 (c)). At $950{ }^{\circ} \mathrm{C}$, essentially complete $\mathrm{Ti}$ 
dissolution occurs after only $0.5 \mathrm{~h}$, as evidenced by the absence of the Ti XRD peaks and the high $\mathrm{TiC}_{\mathrm{x}}$ signal (Figure $\left.6(\mathbf{d})\right)$. These results support the above conclusion that mass transport diffusion through the coating is the rate-limiting process and strongly depends on the coating temperature. A slow diffusion and reaction rate at a low coating temperature favors the formation of non-stoichiometric $\mathrm{TiC}_{\mathrm{x}}$, in which the reactive $\mathrm{Ti}$ sites can be easily oxidized and subsequently results in a graded $\mathrm{TiO}_{\mathrm{y}}-\mathrm{TiC}_{\mathrm{x}}$ coating that contributes better wetting to molten $\mathrm{Cu}$.
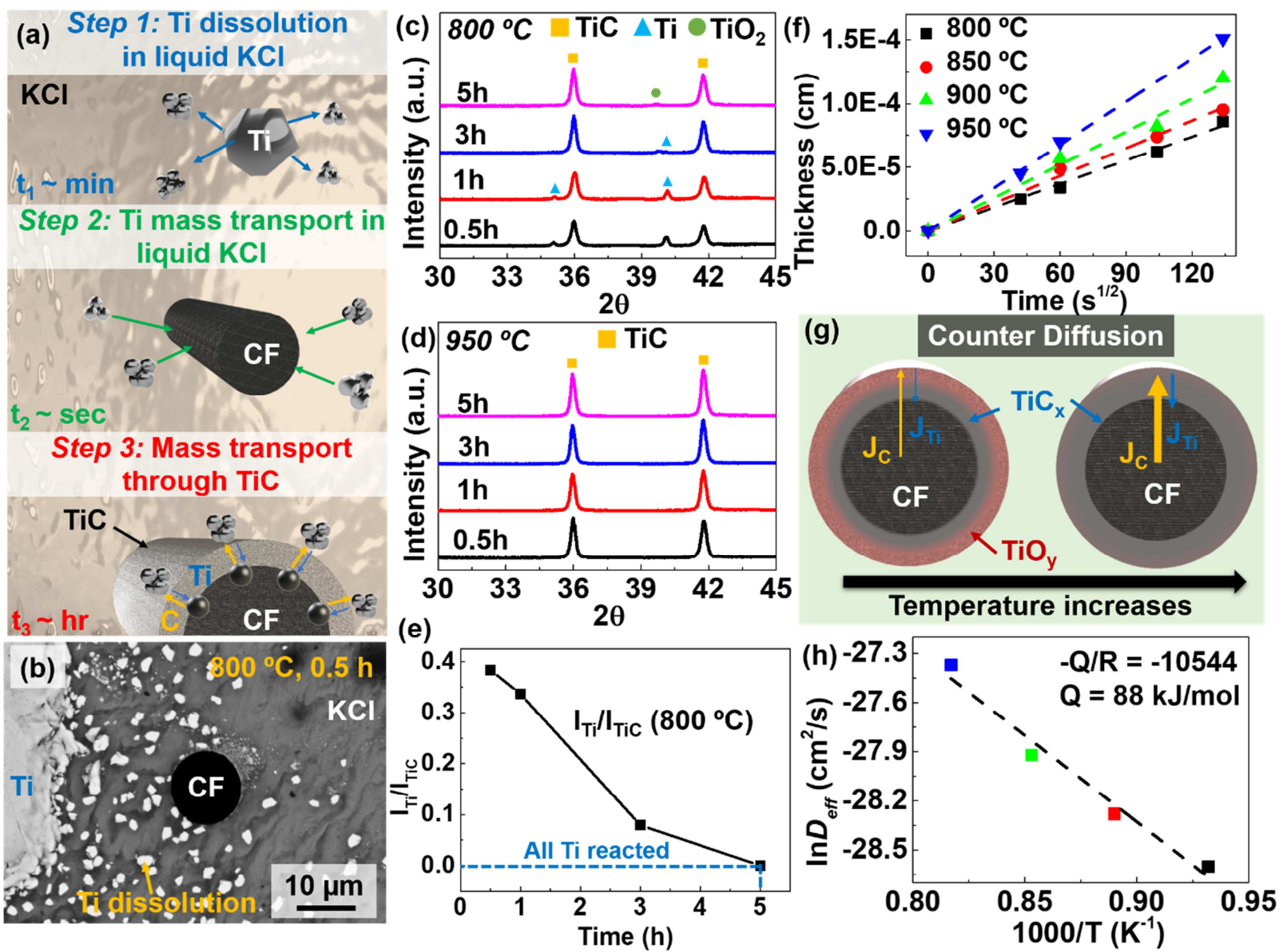

Figure 6. (a) Schematic of the three main steps of a molten-salt coating process, (b) SEM micrographs of rapidly quenched salt at $800{ }^{\circ} \mathrm{C}$ for $0.5 \mathrm{~h}$, XRD diffractograms of washed CFs for coating times ranging from 0.5 to $5 \mathrm{~h}$ at (c) $800{ }^{\circ} \mathrm{C}$ and (d) $950{ }^{\circ} \mathrm{C}$, and (e) $\mathrm{I}_{\mathrm{Ti}} / \mathrm{I}_{\mathrm{TiC}} \mathrm{XRD}$ ratio as functions of the coating time. (f) Coating thickness as a function of the square root of time for 
different coating temperatures; (g) schematic representation of the temperature effect on the graded $\mathrm{TiO}_{\mathrm{y}}-\mathrm{TiC}_{\mathrm{x}}$ coated layer; (h) Arrhenius plot of the natural $\log$ of $D_{\text {eff }}$ versus the inverse of the coating temperature.

To evaluate the counter diffusion at different salt bath temperature, the coating thickness versus the coating time was monitored up to $5 \mathrm{~h}$ between 800 and $950 \square$. As shown in the crosssectional SEM images of the as-prepared coatings (supplemental Figure S8), the coating thickness increases as the coating time and temperature increases. Assuming the simplest case of one-dimensional diffusion mass transport of reactants ( $\mathrm{Ti}$ and $\mathrm{C}$ ) through the coated layer, the growth of the coating thickness can be described as a function of the square root of the coating time, using the following equation [39] :

$$
x=a \sqrt{D_{e f f} t},
$$

where $x$ is the carbide coating thickness $(\mathrm{cm}), a$ is a unit-less proportionally constant (typically set to 2), $t$ is the coating time (s), and $D_{\text {eff }}$ is the effective diffusivity through the layer $\left(\mathrm{cm}^{2} / \mathrm{s}\right)$. As shown in Figure 6 (f), the coating thickness $(x)$ shows a linear increase with the square root of the coating time in agreement with this simple treatment. The effective diffusivities, $D_{\text {eff, }}$ at the different temperatures can be retrieved from the slopes of the curves. The $D_{\text {eff }}$ increased with the coating temperature ranging from a value of $3.8 \times 10^{-13}$ to $1.3 \times 10^{-12} \mathrm{~m}^{2} / \mathrm{s}$ at 800 and $950{ }^{\circ} \mathrm{C}$, respectively. These values reasonably agree with values reported by Koichiro Koyama et al. for the diffusion of $\mathrm{C}$ in $\mathrm{TiC}$ over a temperature range similar to that used in this work [40]. The evaluation of $D_{\text {eff }}$ shows a carbon diffusion more than three-fold lower at $800{ }^{\circ} \mathrm{C}$ than at $950{ }^{\circ} \mathrm{C}$. A slow $\mathrm{C}$ diffusion at a low coating temperature produces a more Ti-rich coating with more reactive non-bonded $\mathrm{Ti}$ sites, thus a higher oxide content in the coated layer as illustrated in Figure 6 (g). 
The $D_{\text {eff }}$ is expected to show an Arrhenius temperature dependence $[41,42]$ :

$$
D_{\text {eff }}=D_{0} e^{\frac{-Q_{e f f}}{R T}}
$$

where $D_{0}$ is the preexponential factor, $Q_{\text {eff }}$ is the activation energy $(\mathrm{J} / \mathrm{mol})$ governing the overall intra-coating diffusion process, and $R$ is the gas constant ( $/ / \mathrm{mol} . \mathrm{K})$. The $Q_{\text {eff }}$ was determined to be $\sim 88 \mathrm{KJ} / \mathrm{mol}$ by linear regression to the data in Figure 6 (h). The activation energy is lower than the one reported by Knuth Albertsen et al. for grain boundary diffusion of $\mathrm{C}$ in bulk $\mathrm{TiC}$ below $1100{ }^{\circ} \mathrm{C}(174 \mathrm{~kJ} / \mathrm{mol})$ [43]; probably due to the enhancement grain boundary diffusion between bulk and coated TiC [43]'[44].

\section{CONCLUSION}

In summary, tailor graded $\mathrm{TiO}_{\mathrm{y}}-\mathrm{TiC}_{\mathrm{x}}$ coatings were synthesized on $\mathrm{CFs}$. The $\mathrm{TiO}_{\mathrm{y}}$ formation was observed after the dissolution of the molten salt in boiling water and is assumed to be the result of oxidation of reactive Ti sites near the exterior coated surface. The oxide-rich carbide coating shows significantly improved wettability by molten $\mathrm{Cu}$ compared to the oxide-carbide rich layer. Notably, the $\mathrm{Cu}$ wetting angle for the $\mathrm{TiO}_{\mathrm{y}}-\mathrm{TiC}_{\mathrm{x}}-\mathrm{CF}$ sample prepared at $800{ }^{\circ} \mathrm{C}$ was $\sim 80^{\circ} \pm 5^{\circ}$ with a $\mathrm{Cu}$ surface coverage of $\sim 50 \%$ versus $\sim 115^{\circ}$ and $\sim 10 \%$ for the $\mathrm{TiC}_{\mathrm{x}}-\mathrm{CF}$ sample made at $950{ }^{\circ} \mathrm{C}$. CFs alone show mostly no $\mathrm{Cu}$ coverage.

By varying the reaction temperature $\left(800-950{ }^{\circ} \mathrm{C}\right)$ and time $(1-5 \mathrm{~h})$ and using rapid thermal quenching, the formation mechanism was investigated. The results indicate a three-step process: 1) A short induction period controlled by rapid Ti dissolution in the molten salt, 2) rapid Ti mass transport in the molten salt and fast reaction at the CFs surface, and 3) mass transport through the layer that is controlled by a combination of titanium and carbon counter-diffusion. 
Fabrication of a graded $\mathrm{TiO}_{\mathrm{y}}-\mathrm{TiC}_{\mathrm{x}}$ coating on $\mathrm{CF}$ substrate via a molten slat process offers a simple way to tailor the properties of CFs. Thus, delivering an efficient route to optimize the properties of metal-carbon interphase. 


\section{AUTHOR INFORMATION}

\section{Author Contributions}

\$ Loic Constantin and Dr. Lisha Fan contributed equally to this work. All authors approved the final version.

\section{$\underline{\text { Acknowledgment }}$}

The authors are gratefully for the financial support provided by the National Science Foundation (CMMI 1826392) and the Nebraska Center for Energy Sciences Research (NCESR). Also, the authors would like to thank Dr. John Campbell for helpful discussions and revisions on the manuscript.

\section{REFERENCES}

[1] M. Hasan, J. Zhao, Z. Jiang, Micromanufacturing of composite materials: a review, Int. J. Extrem. Manuf. 1 (2019) 012004. https://doi.org/10.1088/2631-7990/ab0f74.

[2] S.J. Sun, M.D. Zhang, Interface characteristics and mechanical properties of carbon fibre reinforced copper composites, Journal of Materials Science. 26 (1991) 5762-5766. https://doi.org/10.1007/BF01130112.

[3] J. Koráb, P. Stefánik, Š. Kavecký, P. Šebo, G. Korb, Thermal conductivity of unidirectional copper matrix carbon fibre composites, Composites Part A: Applied Science and Manufacturing. 33 (2002) 577-581. https://doi.org/10.1016/S1359-835X(02)00003-9.

[4] W. Buchgraber, G. Korb, T. Schubert, B. Kempf, Carbon Fibre Reinforced Copper Matrix Composites: Production Routes and Functional Properties, in: Microstructural Investigation and Analysis, Wiley-VCH Verlag GmbH \& Co. KGaA, Weinheim, FRG, 2006: pp. 150155. https://doi.org/10.1002/3527606165.ch22.

[5] J.-F. Silvain, A. Veillère, Y. Lu, Copper-Carbon and Aluminum-Carbon Composites Fabricated by Powder Metallurgy Processes, Journal of Physics: Conference Series. 525 (2014) 012015. https://doi.org/10.1088/1742-6596/525/1/012015.

[6] P. Hidalgo-Manrique, X. Lei, R. Xu, M. Zhou, I.A. Kinloch, R.J. Young, Copper/graphene composites: a review, J Mater Sci. 54 (2019) 12236-12289. https://doi.org/10.1007/s10853019-03703-5.

[7] A.B. Spierings, C. Leinenbach, C. Kenel, K. Wegener, Processing of metal-diamondcomposites using selective laser melting, Rapid Prototyping Journal. (2015). https://doi.org/10.1108/RPJ-11-2014-0156.

[8] L. Constantin, L. Fan, B. Mortaigne, K. Keramatnejad, Q. Zou, C. Azina, Y.F. Lu, J.-F. Silvain, Laser sintering of cold-pressed $\mathrm{Cu}$ powder without binder use, Materialia. 3 (2018) 178-181. https://doi.org/10.1016/j.mtla.2018.08.021. 
[9] K. Yoshida, H. Morigami, Thermal properties of diamond/copper composite material, Microelectronics Reliability. 44 (2004) 303-308. https://doi.org/10.1016/S00262714(03)00215-4.

[10] L. Xia, B. Jia, J. Zeng, J. Xu, Wear and mechanical properties of carbon fiber reinforced copper alloy composites, Materials Characterization. 60 (2009) 363-369. https://doi.org/10.1016/J.MATCHAR.2008.10.008.

[11] Q. Kang, X. He, S. Ren, L. Zhang, M. Wu, C. Guo, W. Cui, X. Qu, Preparation of copperdiamond composites with chromium carbide coatings on diamond particles for heat sink applications, Applied Thermal Engineering. 60 (2013) 423-429. https://doi.org/10.1016/J.APPLTHERMALENG.2013.05.038.

[12] C.R. Rambo, N. Travitzky, P. Greil, Conductive TiC/Ti-Cu/C composites fabricated by Ti$\mathrm{Cu}$ alloy reactive infiltration into 3D-printed carbon performs, Journal of Composite Materials. 49 (2015) 1971-1976. https://doi.org/10.1177/0021998314541307.

[13] X. QU, L. ZHANG, M. WU, S. REN, Review of metal matrix composites with high thermal conductivity for thermal management applications, Progress in Natural Science: Materials International. 21 (2011) 189-197. https://doi.org/10.1016/S1002-0071(12)60029$\mathrm{X}$.

[14] K. Chu, C. Jia, H. Guo, W. Li, Microstructure and thermal conductivity of $\mathrm{Cu}-\mathrm{B} /$ diamond composites, Journal of Composite Materials. 47 (2013) 2945-2953. https://doi.org/10.1177/0021998312460259.

[15] Th. Schubert, B. Trindade, T. Weißgärber, B. Kieback, Interfacial design of Cu-based composites prepared by powder metallurgy for heat sink applications, Materials Science and Engineering: A. 475 (2008) 39-44. https://doi.org/10.1016/J.MSEA.2006.12.146.

[16] K. Chu, C. Jia, H. Guo, W. Li, On the thermal conductivity of $\mathrm{Cu}-\mathrm{Zr} /$ diamond composites, Materials \& Design. 45 (2013) 36-42. https://doi.org/10.1016/J.MATDES.2012.09.006.

[17] Y. Zhang, H.L. Zhang, J.H. Wu, X.T. Wang, Enhanced thermal conductivity in copper matrix composites reinforced with titanium-coated diamond particles, Scripta Materialia. 65 (2011) 1097-1100. https://doi.org/10.1016/j.scriptamat.2011.09.028.

[18] Z.J. Dong, X.K. Li, G.M. Yuan, Y. Cong, N. Li, Z.Y. Jiang, Z.J. Hu, Fabrication and oxidation resistance of titanium carbide-coated carbon fibres by reacting titanium hydride with carbon fibres in molten salts, Thin Solid Films. 517 (2009) 3248-3252. https://doi.org/10.1016/j.tsf.2008.11.046.

[19] H.O. Pierson, Handbook of refractory carbides and nitrides : properties, characteristics, processing, and applications, Noyes Publications, 1996.

[20] D.A. Mortimer, M. Nicholas, The wetting of carbon and carbides by copper alloys, Journal of Materials Science. 8 (1973) 640-648. https://doi.org/10.1007/BF00561219.

[21] X. Li, Z. Dong, A. Westwood, A. Brown, R. Brydson, A. Walton, G. Yuan, Z. Cui, Y. Cong, Low-Temperature Preparation of Single Crystal Titanium Carbide Nanofibers in Molten Salts, Crystal Growth \& Design. 11 (2011) 3122-3129. https://doi.org/10.1021/cg200386d.

[22] T. Kimura, Molten Salt Synthesis of Ceramic Powders, in: Advances in Ceramics Synthesis and Characterization, Processing and Specific Applications, InTech, 2011. https://doi.org/10.5772/20472.

[23] X. Liu, Z. Wang, S. Zhang, Molten Salt Synthesis and Characterization of Titanium Carbide-Coated Graphite Flakes for Refractory Castable Applications, International Journal 
of Applied Ceramic Technology. 8 (2011) 911-919. https://doi.org/10.1111/j.17447402.2010.02529.x.

[24] A. Le Bail, H. Duroy, J.L. Fourquet, Ab-initio structure determination of LiSbWO6 by Xray powder diffraction, Materials Research Bulletin. 23 (1988) 447-452. https://doi.org/10.1016/0025-5408(88)90019-0.

[25] Q. Liu, X.-B. He, S.-B. Ren, T. Liu, Q.-P. Kang, X.-H. Qu, Effect of titanium carbide coating on the microstructure and thermal conductivity of short graphite fiber/copper composites, J Mater Sci. 48 (2013) 5810-5817. https://doi.org/10.1007/s10853-013-7373-y.

[26] Z.J. Dong, X.K. Li, G.M. Yuan, Z.W. Cui, Y. Cong, A. Westwood, Tensile strength, oxidation resistance and wettability of carbon fibers coated with a TiC layer using a molten salt method, Materials \& Design. 50 (2013) 156-164. https://doi.org/10.1016/j.matdes.2013.02.084.

[27] E. Morton, R.K. Lewis, CONTRACT NO. NAW-663 FINAL REPORT PROPERTIES OF NON-STOICHIOMETRIC METALLIC CARBIDES, Mendeley. (n.d.). https://www.mendeley.com/catalogue/contract-naw663-final-report-propertiesnonstoichiometric-metallic-carbides/ (accessed February 6, 2019).

[28] N. Frage, L. Levin, E. Manor, R. Shneck, J. Zabicky, Iron-titanium-carbon system. II. Microstructure of titanium carbide ( $\mathrm{TiCx}$ ) of various stoichiometries infiltrated with ironcarbon alloy, Scripta Materialia. 35 (1996) 799-803. https://doi.org/10.1016/13596462(96)00230-8.

[29] J. Roger, B. Gardiola, J. Andrieux, J.-C. Viala, O. Dezellus, Synthesis of Ti matrix composites reinforced with TiC particles: thermodynamic equilibrium and change in microstructure, Journal of Materials Science. 52 (2017) 4129-4141. https://doi.org/10.1007/s10853-016-0677-y.

[30] E. Fryt, Defect mobility in TiC1 - $\mathrm{x}$ at high temperatures, Solid State Ionics. 101-103 (1997) 437-443. https://doi.org/10.1016/S0167-2738(97)00139-2.

[31] I. Dahan, U. Admon, N. Frage, J. Sariel, M.P. Dariel, Diffusion in Ti/TiC multilayer coatings, Thin Solid Films. 377-378 (2000) 687-693. https://doi.org/10.1016/S00406090(00)01282-7.

[32] S. Sarian, Diffusion of ${ }^{44} \mathrm{Ti}_{\text {in TiC }}$, Journal of Applied Physics. 40 (1969) 3515-3520. https://doi.org/10.1063/1.1658229.

[33] T. Matsumoto, H. Fujii, T. Ueda, M. Kamai, K. Nogi, Measurement of surface tension of molten copper using the free-fall oscillating drop method, Meas. Sci. Technol. 16 (2005) 432-437. https://doi.org/10.1088/0957-0233/16/2/014.

[34] B. Kong, J. Ru, H. Zhang, T. Fan, Enhanced wetting and properties of carbon/carbon-Cu composites with $\mathrm{Cr} 3 \mathrm{C} 2$ coatings by Cr-solution immersion method, Journal of Materials Science \& Technology. 34 (2018) 458-465. https://doi.org/10.1016/j.jmst.2017.01.028.

[35] D.A. Mortimer, M. Nicholas, The wetting of carbon and carbides by copper alloys, J Mater Sci. 8 (1973) 640-648. https://doi.org/10.1007/BF00561219.

[36] N. Eustathopoulos, B. Drevet, Interfacial bonding, wettability and reactivity in metal/oxide systems, Journal de Physique III. 4 (1994) 1865-1881. https://doi.org/10.1051/jp3:1994244.

[37] H. Sekimoto, Y. Nose, T. Uda, H. Sugimura, Quantitative Analysis of Titanium Ions in the Equilibrium with Metallic Titanium in NaCl-KCl Equimolar Molten Salt, MATERIALS TRANSACTIONS. 51 (2010) 2121-2124. https://doi.org/10.2320/matertrans.M2010238. 
[38] W.C. Kreye, H.H. Kellogg, The Equilibrium between Titanium Metal, TiCl2, and TiCl3 in $\mathrm{NaCl} \square \mathrm{KCl}$ Melts, J. Electrochem. Soc. 104 (1957) 504-508. https://doi.org/10.1149/1.2428636.

[39] C.R. Clayton, Materials science and engineering: An introduction, Materials Science and Engineering. 94 (n.d.) 266-267.

https://www.academia.edu/8089620/Materials_Science_and_Engineering_An_Introduction _EIGHTH_EDITION_by_William_D._Callister_Jr_and_David_G._Rethwisch (accessed June 13, 2019).

[40] K. Koyama, Y. Hashimoto, S. Omori, Diffusion of Carbon in TiC, Trans. JIM. 16 (1975) 211-218. https://doi.org/10.2320/matertrans 1960.16.211.

[41] T. Arai, Carbide coating process by use of molten borax bath in Japan, Journal of Heat Treating. 1 (1979) 15-22. https://doi.org/10.1007/BF02833234.

[42] J. Roger, F. Audubert, Y. Le Petitcorps, Thermal reaction of SiC films with tungsten and tungsten-rhenium alloys, Journal of Materials Science. 43 (2008) 3938-3945. https://doi.org/10.1007/s10853-007-2334-y.

[43] K. Albertsen, H.-J. Schaller, Diffusion of C in TiC, Berichte Der Bunsengesellschaft Für Physikalische Chemie. 98 (1994) 1224-1230. https://doi.org/10.1002/bbpc.19940981003.

[44] D.D. Himbeault, R.A. Varin, K. Piekarski, Carbon fibers coated with chromium carbide using the liquid metal transfer agent technique, MTA. 20 (1989) 165-170.

https://doi.org/10.1007/BF02647503. 


\section{Declaration of interests}

The authors declare that they have no known competing financial interests or personal relationships that could have appeared to influence the work reported in this paper.

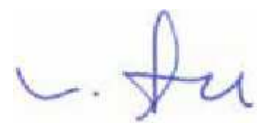

Yongfeng $\mathrm{Lu}, \mathrm{PhD}$

Lott Distinguished Professor of Electrical and Computer Engineering, Mechanical and Materials Engineering SPIE, LIA, OSA, and IAPLE Fellow

Past President, International Academy of Photonics and Laser Engineering (IAPLE, UK).

Past President, Laser Institute of America (LIA, USA)

Editor-in-Chief, Journal of Laser Applications (LIA and AIP, USA)

International Editor-in-Chief, International Journal of Extreme Manufacturing

419 Nebraska Hall,

University of Nebraska Lincoln,

Lincoln, NE 68588-0511.

Tel: 402-472-8323; Cell: 402-617-3509; Fax: 402-472-4732

Email: ylu2@unl.edu 